\title{
Molecular and Physiological Diversity of Nicotinic Acetylcholine Receptors in the Midbrain Dopaminergic Nuclei
}

\author{
Ruby Klink, ${ }^{1}$ Alban de Kerchove d'Exaerde, ${ }^{1}$ Michele Zoli,, ${ }^{1,2}$ and Jean-Pierre Changeux ${ }^{1}$ \\ ${ }^{1}$ Laboratoire de Neurobiologie Moléculaire, Centre National de la Recherche Scientifique Unité de Recherche Associée \\ 2182 "Récepteurs et Cognition," Institut Pasteur, 75724 Paris Cédex 15, France, and 2Department of Biomedical \\ Sciences, Section of Physiology, University of Modena and Reggio Emilia, 41100 Modena, Italy
}

Nicotinic acetylcholine receptors (nAChRs) on dopaminergic (DA) and GABAergic (Gaba) projection neurons of the substantia nigra (SN) and ventral tegmental area (VTA) are characterized by single-cell RT-PCR and patch-clamp recordings in slices of rat and wild-type, $\beta 2-/-, \alpha 4-/-$, and $\alpha 7-/-$ mice. The eight nAChR subunits expressed in these nuclei, $\alpha 3-7$ and $\beta 2-4$, contribute to four different types of nAChR-mediated currents. Most DA neurons in the SN and VTA express two nAChR subtypes. One is inhibited by dihydro- $\beta$-erythroidine $(2 \mu \mathrm{M})$, $\alpha$-conotoxin MII (10 nM), and methyllycaconitine (1 nM) but does not contain the $\alpha 7$ subunit; it possesses a putative $\alpha 4 \alpha 6 \alpha 5(\beta 2)_{2}$ composition. The other subtype is inhibited by dihydro- $\beta$ - erythroidine $(2 \mu \mathrm{M})$ and has a putative $\alpha 4 \alpha 5(\beta 2)_{2}$ composition. Gaba neurons in the VTA exhibit a third subtype with a putative $(\alpha 4)_{2}(\beta 2)_{3}$ composition, whereas Gaba neurons in the SN have either the putative $(\alpha 4)_{2}(\beta 2)_{3}$ oligomer or the putative $\alpha 4 \alpha 6 \alpha 5(\beta 2)_{2}$ oligomer. The fourth subtype, a putative $(\alpha 7)_{5}$ homomer, is encountered in less than half of DA and Gaba neurons, in the SN as well as in the VTA. Neurons in the DA nuclei thus exhibit a diversity of $n A C h R s$ that might differentially modulate reinforcement and motor behavior.

Key words: addiction; dopamine; GABA; nAChR; nicotinic; Parkinson's disease; substantia nigra; ventral tegmental area
The midbrain dopaminergic (DA) nuclei comprising the substantia nigra (SN) and ventral tegmental area (VTA) play key roles in motility, reinforcement, and associative motor learning (Berke and Hyman, 2000). Nicotinic acetylcholine receptors (nAChRs) are densely distributed in the SN and VTA (Fallon and Loughlin, 1995) and are probably implicated in the regulation of the dopaminergic circuits in several pathophysiological conditions, such as nicotine addiction (O'Brien and McLellan, 1996) and the nicotine-mediated protection against Parkinson's disease (Baron, 1986; Fuxe et al., 1990). To develop pharmacological agents selectively targeted to the different midbrain nicotinic functions, identification of the nAChR subtypes becomes imperative.

Distinguishing between the various native $\mathrm{nAChR}$ subtypes and defining their subunit composition is a major challenge, and especially so in the DA midbrain. Of the nine $\mathrm{nAChR}$ subunits identified so far in the mammalian CNS, seven were found in the SN-VTA; the mRNA for five of them $(\alpha 4, \alpha 5, \alpha 6, \beta 2, \beta 3)$ was expressed at high levels, and of those, at least $\alpha 6$ and $\beta 3$ are thought to be present largely in tyrosine hydroxylase (TH)-

\footnotetext{
Received Sept. 21, 2000; revised Nov. 29, 2000; accepted Dec. 5, 2000.

This work was supported by the Collège de France, the Centre National de la Recherche Scientifique, the Council for Tobacco Research, the Association pour la Recherche sur le Cancer and the Commission of the European Communities (CEC). R.K. is supported by salary from the Collège de France; A.deK.d'E. is supported by the CEC; M.Z. is a recipient of a Telethon and a Ministero dell'Universitá e della Ricerca Scientifica e Tecnologica Cofin2000 Italian grant. We thank Dr. Clément Léna for technical help regarding RT-PCR procedures, Dr. Richard Miles for useful comments, Dr. Arthur Beaudet (Baylor College of Medicine, Houston, TX) for providing the $\alpha 7$ knock-out mice, and Dr. Lisa Marubio for the gift of $\alpha 4$ knock-out mice. R.K. and A.deK.d'E. contributed equally to this work.

Correspondence should be addressed to Jean-Pierre Changeux, Unité de Neurobiologie Moléculaire, Département des Biotechnologies, Institut Pasteur, 28 rue de Dr. Roux, 75724 Paris Cedex 15, France. E-mail: changeux@pasteur.fr.

Dr. de Kerchove d'Exaerde's present address: Laboratory of Neurophysiology, Department of Neuroscience, CP601, Université Libre de Bruxelles, School of Medicine 808, route de Lennik 1070 Brussels, Belgium.

Copyright (C) 2001 Society for Neuroscience 0270-6474/01/211452-12\$15.00/0
}

containing DA neurons (Le Novère et al., 1996). In addition, the presence of $\alpha 7$ was detected in the SN (from mRNA) (Elliott et al., 1998) and inferred in some DA neurons of the VTA from electrophysiological studies (Pidoplichko et al., 1997). Binding studies revealed high-affinity nicotinic binding sites in the SN-VTA as well as in their striatal terminal fields (Clarke and Pert, 1985); further studies performed in $\beta 2$ (Picciotto et al., 1995; Zoli et al., 1998) and $\alpha 4$ (Marubio et al., 1999) null mutant mice demonstrated the critical role of subunits $\beta 2$ and $\alpha 4$ in this high-affinity binding. Functional studies have focused on the pharmacology of dopamine release in striatal synaptosomes and slices [Sharples et al. (2000) and references therein]. Although hampered by a lack of subtypespecific tools, they suggested the presence of more than one nAChR subtype, comprising a putative $\alpha 3 \beta 2$ ligand binding interface (Kaiser et al., 1998) but exhibiting a subunit combination distinct from that of any of the oligomers commonly reconstituted in expression systems (Kulak et al., 1997). Finally, in vivo approaches have conclusively implicated $\beta 2 *$-nAChR subtype(s) in nicotine self-administration and nicotine-elicited dopamine release (Picciotto et al., 1998). Other in vivo studies have suggested that an $\alpha 7$-homomeric nAChR subtype in the VTA was involved in nicotine-elicited dopamine release (Schilstrom et al., 1998) and in the nicotine withdrawal syndrome (Nomikos et al., 1999).

In this work, we further investigate the identification of $\mathrm{nAChR}$ subtypes present in midbrain DA nuclei. From single-cell studies in the $\mathrm{SN}$ compacta $(\mathrm{SNc}), \mathrm{SN}$ reticulata $(\mathrm{SNr})$, and VTA of rat and nAChR-subunit null mutant mice, we reveal that projection neurons in these areas show diverse nAChR subtypes, and that one of them, present on DA neurons, is endowed with a hitherto undescribed pharmacological profile.

\section{MATERIALS AND METHODS}

Slice preparation and electrophysiological recordings. Coronal, horizontal, or sagittal $300 \mu \mathrm{m}$ slices were obtained from the midbrain of Sprague 
Dawley rats (13-25 d) and wild-type (WT), $\beta 2, \alpha 4$, and $\alpha 7$ null mutant mice (11-16 d), incubated in oxygenated ACSF containing $1 \mathrm{~mm}$ kynurenic acid at $\sim 32^{\circ} \mathrm{C}$ for $0.5 \mathrm{hr}$, then left at room temperature for an additional $0.5 \mathrm{hr}$. ACSF composition was as follows (in mM): $126 \mathrm{NaCl}$, $26 \mathrm{NaHCO}_{3}, 2.5 \mathrm{KCl}, 2 \mathrm{CaCl}_{2}, 1.25 \mathrm{NaH}_{2} \mathrm{PO}_{4}, 1 \mathrm{MgCl}_{2}, 25$ glucose. For recording, a single slice was transferred to a chamber superfused with oxygenated ACSF at $35 \pm 0.5^{\circ} \mathrm{C}$ at a rate of $2 \mathrm{ml} / \mathrm{min}$. Whole-cell recordings were obtained from $\mathrm{SNc}, \mathrm{SNr}$, and VTA neurons identified using infrared videomicroscopy with Nomarski optics. Only presumptive projection neurons of large and medium size were targeted; presumputive interneurons of small size were avoided. Patch pipettes were filled with the following (in $\mathrm{mM}$ ): $144 \mathrm{~K}$-gluconate, $10 \mathrm{HEPES}, 3 \mathrm{MgCl}_{2}, 0.2$ EGTA, pH 7.2, yielding a 3-5 M $\Omega$ resistance. Recordings were done with an Axoclamp-2A (Axon Instruments, Foster City, CA) amplifier operating under current-clamp or continuous voltage-clamp mode, filtered at 3 $\mathrm{kHz}$, and stored on digital tape for later analysis. After completion of the experiment, a video image of the field of view was saved to confirm the location of the neuron recorded from, by comparison with a rat brain atlas (Paxinos and Watson, 1986). Data were subsequently acquired (10-50 kHz; InstruNet board, GW I, Sommerville, MA) and analyzed (IgorPro software, ver 3.1, Wavemetrics, Lake Oswego, OR). Some traces were digitally filtered for display.

Drug administration. Fast application of agonist was achieved by pressure-pulse delivery (14 psi) to a two-channel, theta style pipette (diameter 3.5-4 $\mu \mathrm{M}$ ) positioned under visual control at $\sim 30 \mu \mathrm{M}$ from the targeted cell. This allowed sequential, rapid application of two agonists onto the same neuron, and thus a between-agonists comparison of induced currents on a truly cell-by-cell basis, without drawbacks associated with slower drug application systems. Mechanical removal of agonist from the vicinity of the activated receptors, caused by diff usion into the slice tissue and constant perfusion of ACSF, was similar for all agonists because the application pipette was always in the same position relative to the targeted cell. Quantified kinetic parameters of agonist-elicited current waveforms were compared only for the same agonist ( $\mathrm{ACh}$ ) so that intrinsic removal of agonist caused by uptake and degradation would be identical. For all agonists, response latency (time between beginning of pressure pulse and a detectable response) was $12-63 \mathrm{msec}$. Agonists were dissolved in ACSF to the specified concentration before filling of the drug application pipette. Agonists were acetylcholine chloride (ACh), choline chloride (choline), nicotine tartrate (nicotine), and cytisine (all from Sigma-Aldrich); atropine (1 $\mu \mathrm{M}$; Sigma-Aldrich) was present in the ACSF when ACh was applied. Antagonists were bathperfused for $10 \mathrm{~min}$ before pressure-pulse applications of agonists. Additional perfusion did not increase the extent of inhibition for any of the antagonists tested. Antagonists were dihydro- $\beta$-erythroidine hydrobromide $(\mathrm{DH} \beta \mathrm{E})$, methyllycaconitine citrate (MLA) (both from RBI/ Sigma-Aldrich), and $\alpha$-conotoxin MII (Eurogentec) stock solution dissolved in $50 \mathrm{~mm}$ Tris $+0.1 \mathrm{mg} / \mathrm{ml} \mathrm{BSA}$ (perfusion of Tris did not affect agonist-elicited nicotinic currents; $n=2$ ).

Cytoplasm harvest and single cell RT-PCR. When required, at the end of the recording, the cytoplasm was retrieved by aspiration into the recording pipette under visual control; the contents were expelled into a test tube in which the RT reaction was performed in a final volume of $10 \mu \mathrm{l}$ (Lambolez et al., 1992) and left overnight at $37^{\circ} \mathrm{C}$. PCR amplification was performed for detection of the two GABA synthetizing enzymes GAD 65 and GAD 67, tyrosine hydroxylase (TH), calbindin (CB), calretinin (CR), parvalbumin (PV), cholecystokinin (CCK), neurotensin (NT), and the nAChR subunits $\alpha 2-\alpha 7$ and $\beta 2-\beta 4$. The possibility of contamination by $\mathrm{nAChR}$ subunit cDNAs used in the laboratory was ruled out by inclusion of a template minus negative control (extracellular solution near harvested neurons).

After analyzing results of the single-cell PCR experiments, the $\beta 2$ band was found absent or difficult to interpret in 32 of 79 neurons. This result is at odds with previous in situ hybridization (Le Novère et al., 1996) and immunocytochemical (Hill et al., 1993) analysis of the $\beta 2$ subunit in the midbrain area, which showed $\beta 2$ mRNA or protein expression in practically all neurons. We therefore decided to synthesize a second set of oligonucleotides ( $\beta 2$ For 2 and $\beta 2 \mathrm{Rev}$; see below). With the new set of oligonucleotides, a clear $\beta 2$ band was detected with single-cell PCR. The experiment was repeated in a small sample of DA neurons, and $\beta 2$ mRNA was detected in nine of nine neurons with the new oligonucleotides but only in five of nine with the old oligonucleotides ( $\beta 2$ For and $\beta 2 \beta 4 \mathrm{Rev}$; see below). The frequency distribution reported for the $\beta 2$ mRNA is most probably underestimated. The other subunits (see Discussion) apparently were not associated with similar detection problems.

Multiplex PCR. The set of primers used were located in different exons to rule out genomic DNA amplification by size criterion. The two steps of multiplex PCR were performed as described previously (Léna et al., 1999). The resulting cDNAs of nAChR subunits $\alpha 2-7, \beta 2-4$, GAD65, GAD67, TH, CB, CCK, CR, NT, and PV contained in $10 \mu \mathrm{l}$ RT reaction were first amplified simultaneously. Taq polymerase (2.5 U) (Qiagen, Hilden, Germany) and 10 pmol of each of the 31 primers were added in the buffer supplied by the manufacturer (final volume $100 \mu \mathrm{l}$ ), and 20 cycles $\left(94^{\circ} \mathrm{C}, 1 \mathrm{~min} ; 60^{\circ} \mathrm{C}, 1 \mathrm{~min} ; 72^{\circ} \mathrm{C}, 1 \mathrm{~min}\right)$ of PCR were run. Second rounds of PCR were then performed using $2 \mu \mathrm{l}$ of the first PCR as template (final volume $50 \mu \mathrm{l}$ ). In this second PCR, each cDNA was amplified individually using its specific primer pair (except for GAD65 and GAD67, which were amplified together) by performing 40 PCR cycles as described above. Twenty microliters of each individual PCR were then run on a $2 \%$ agarose gel. To confirm the specificity of PCR product, the last $30 \mu \mathrm{l}$ were purified on QIAquick spin column (Qiagen) and restricted with specific endonucleases. The products that were digested yielded uniquely identifying fragments. The efficiency of this RT-multiplex PCR protocol was tested on $1 \mathrm{ng}$ of whole-brain total RNA (Léna et al., 1999; Porter et al., 1999). The following sets of primers were used (from $5^{\prime}$ to $3^{\prime}$; position 1 is the first base of the start codon, and the number between brackets indicates the initial and final positions of the PCR primers). Specific endonucleases for the different cDNAs and their cut position are also between brakets: $\alpha 2$ (accession number L10077) $\alpha 2$ For [325-351], $\alpha 2 \alpha 4$ Rev [880-908] (Léna et al., 1999) NdeI [546]; $\alpha 3$ (accession number L31621) $\alpha 3$ For [301-327], $\alpha 3$ Rev [843-870] (Léna et al., 1999) Ava I [619]; $\alpha 4$ (accession number L31620) $\alpha 4$ For [337-356], $\alpha 4$ Rev [581-601] (Porter et al., 1999) AatII [496]; $\alpha 5$ (accession number J05231) $\alpha 5$ For [1102-1121], $\alpha 5 \operatorname{Rev}$ [1369-1392] (Porter et al., 1999) AatII [1187]; $\alpha 6$ (accession number L08227) $\alpha 6$ For [417-441], $\alpha 6$ Rev [1014-1034] (Léna et al., 1999) EcoRV [685]; $\alpha 7$ (accession number L31619) $\alpha 7$ For [264-293], $\alpha 7$ Rev [746-773] (Léna et al., 1999) HaeII [359]; $\beta 2$ (accession number L31622) $\beta 2$ For [308-335], $\beta 2 \beta 4$ Rev [859-884] (Poth et al., 1997) HinFI [649], $\beta 2$ For2 [10-29], $\beta 2$ Rev [264-283] BspHI [223]; $\beta 3$ (accession number J04636) $\beta 3$ For [334-360], $\beta 3$ Rev [772-799] (Léna et al., 1999) NcoI [479, 554]; $\beta 4$ (accession number U42976) $\beta 4$ For [284-310], $\beta 2 \beta 4$ Rev [853-878] (Poth et al., 1997) AflII [547]; GAD 65 (accesion number M72422) GAD65 For [713-732], GAD65-67 Rev [1085-1103] (Cauli et al., 1997); GAD67 (accession number M76177) GAD67 For [529-547], GAD65-67 Rev [1109-1127] (Cauli et al., 1997); TH (accession number NM012740) TH For [36-65], TH Rev [581-610] (Léna et al., 1999) BanI [408]; CB (accession number M27839) CB For [130-156], CB Rev [544-570] (Cauli et al., 1997) EcoRI [304]; CCK (accession number K01259) CCK For [170-196], CCK Rev[366-392] (Cauli et al., 1997) PstI [247]; CR (accession number X66974) CR For [138-164], CR Rev [425-451] (Cauli et al., 1997) Eco 47 III [325]; NT (accession number J03185) NT For [30-56], NT Rev [375-401] SphI [120]; PV (accession number) M12725) PV For [115-141], PV Rev [473-502] (Cauli et al., 1997) EcoRI [304].

Statistical analysis. Statistical analysis was done with StatView software (SAS Institute). Averages are given as mean \pm SEM; means were compared with the Student's $t$ test (two-tailed, paired or unpaired) or post hoc analysis of one-way ANOVA, and frequency distributions were compared with the $\chi^{2}$ test (significance level 0.05).

\section{RESULTS \\ Physiological and molecular profile of $\mathrm{SN}$ and VTA neurons}

Whole-cell recordings were obtained from presumptive projection neurons of large and medium size in rat $\mathrm{SNr}, \mathrm{SNc}$, and VTA at all rostrocaudal levels. A detailed electrophysiological characterization of firing and membrane potential properties, followed by single-cell RT-PCR, was performed on 79 neurons.

Two main electrophysiological classes composed of neurons of similar morphology and size were distinguished in each of the SNcs, SNrs, and VTAs (Table 1). One was typical of the THcontaining, DA neurons already extensively characterized (Grace and Onn, 1989; Yung et al., 1991). In the present study, only slight differences were observed between DA neurons of the SNc and SNr and those of the VTA (Fig. 1); we refer to neurons from this 


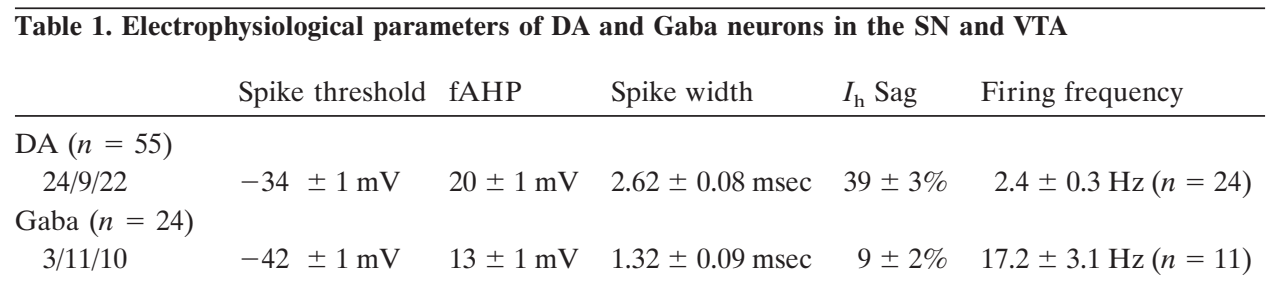

Number of neurons in each of the SNc/SNr/VTA is indicated below neuron class label. All quantified parameters were significantly different $(p<0.001)$ between DA and Gaba neurons. Fast afterhyperpolarization (fAHP) was measured from threshold; spike width was measured at threshold; $I_{\mathrm{h}}$ sag quantifies the time-dependent relaxation in the voltage response to hyperpolarizing current steps, indicative of $I_{\mathrm{h}}$ current activation; firing frequency was evaluated at the resting membrane potential in spontaneously active neurons.
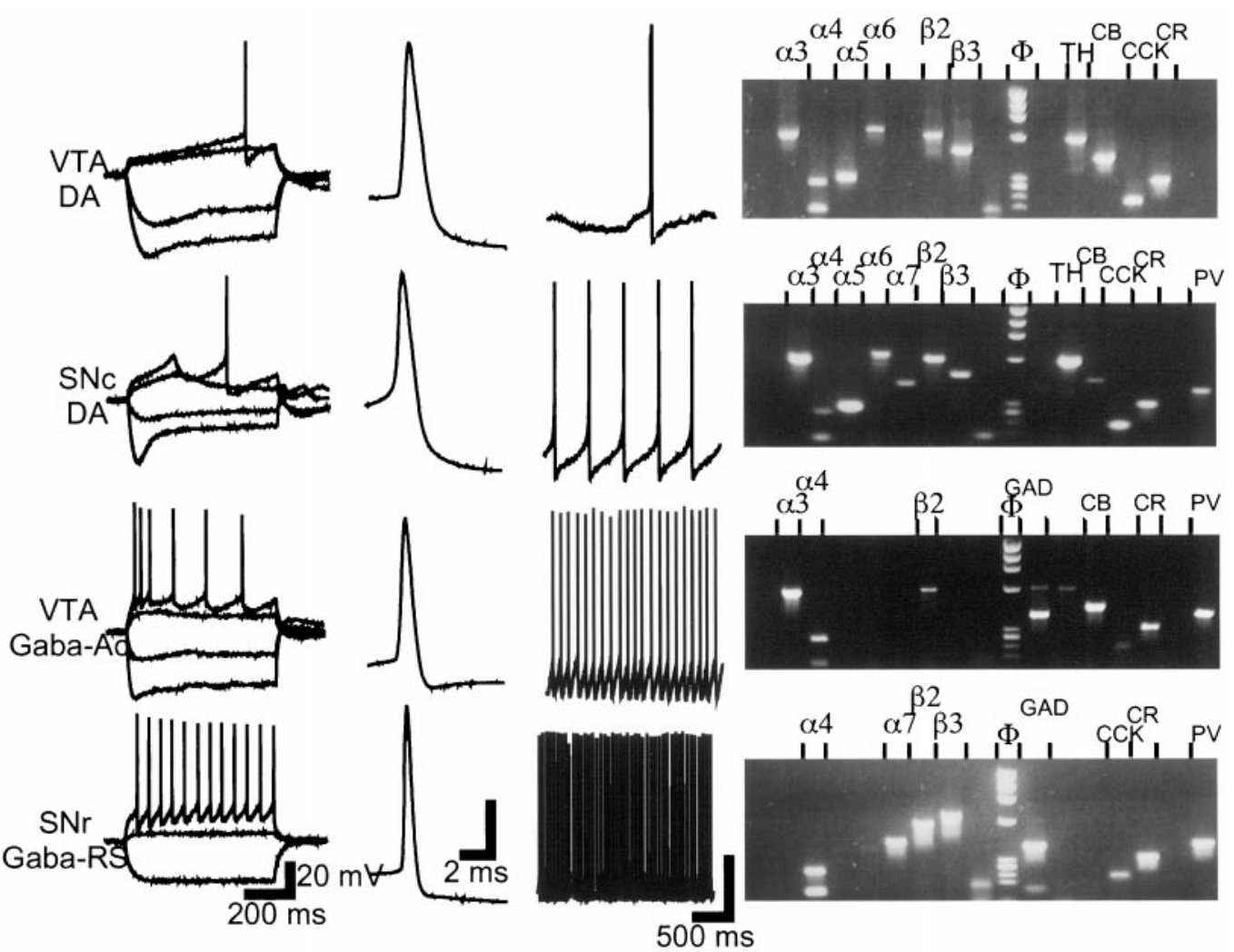

Figure 1. Electrophysiological and molecular profile of VTA and SN neurons. Electrophysiological classes were distinguished on the basis of intrinsic membrane potential and firing properties in response to current steps applied from $-64 \mathrm{mV}$ ( first panel from left); on action potential waveform and duration, measured at rheobase current (second panel); and on firing frequency at the resting membrane potential for neurons that were spontaneously active (third panel). DA neurons in the SNc and $\mathrm{SNr}$ were indistinguishable; they exhibited strong $I_{\mathrm{b}}$ activation and slow potential oscillations in the subthreshold range. DA neurons in the VTA showed a less pronounced $I_{\mathrm{h}}$ activation and a slow ramp potential before firing initiation. Gaba-Ac neurons in the VTA were characterized by marked spike-frequency accommodation in response to depolarizing current steps. Gaba-RS neurons in the SNr fired with a regular discharge pattern, at all amplitudes of depolarizing current steps and from depolarized as well as hyperpolarized holding potentials. Vertical calibration bar is $20 \mathrm{mV}$ in all three panels. The right panel shows agarose gels of the PCR amplification products corresponding to the illustrated neuron. Only detected products are labeled (left to right): nicotinic subunits $\alpha 2-7$ and $\beta 2-4$, marker, GAD (GAD 65 and GAD 67), TH, CB, CCK, CR, NT, and PV. The gel for the GABA-Ac neuron (third from top) shows a faint TH band; such (rare) TH bands were discounted. When GAD and TH were coexpressed (see Results) both bands were of equal intensity.

group as DA neurons. Neurons in the other electrophysiological class, generally denoted as non-DA, were referred to as Gaba neurons because their molecular phenotype was confirmed by single-cell RT-PCR. We have encountered two subclasses of Gaba neurons in the SNc and $\mathrm{SNr}$ and two different ones in the VTA. The major subclass in the SNc/SNr (12 of 15 Gaba neurons) exhibited a regular spiking pattern on application of a depolarizing current pulse (Fig. 1); we denote this subclass as Gaba-regular spiking (Gaba-RS). The major subclass in the VTA (six of nine Gaba neurons) exhibited a strongly accommodating firing pattern (Fig. 1); we denote this subclass as Gabaaccommodating (Gaba-Ac). The intrinsic membrane potential properties of Gaba-Ac neurons were unlike those of neocortical GABAergic neurons (Cauli et al., 1997) but resembled those of an infrequent hippocampal subclass (R. Miles, personal communication). We found it necessary to maintain the distinction between Gaba neuron subclasses throughout, because the biophysical and pharmacological properties of their nAChRmediated currents differed.

Single-cell RT-PCR was performed to assay the differential 
A

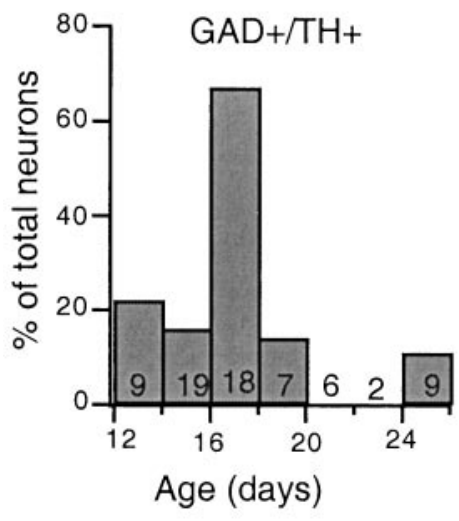

B1
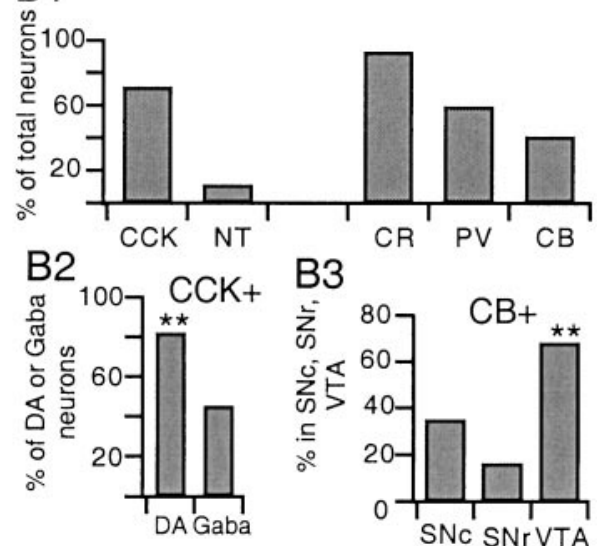

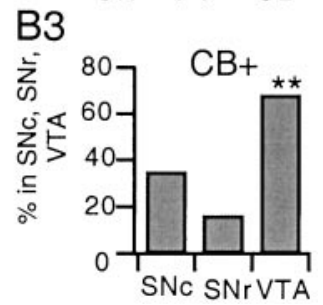

Figure 2. Frequency distribution of mRNAs for neurotransmitter synthesizing enzymes, neuropeptides, and $\mathrm{Ca}^{2+}$-binding proteins in SN and VTA. $A$, Percentage of neurons coexpressing GAD and TH mRNA versus age; numbers at the base of histogram bars indicate the total number of neurons in each age group bin $(2 \mathrm{~d})$. B1, Percentage of neurons expressing the neuropeptides CCK and NT and the $\mathrm{Ca}^{2+}$-binding proteins $\mathrm{CR}, \mathrm{PV}$, and CB. B2, Percentage of DA and Gaba neurons that are CCK positive. CCK is preferentially expressed in DA neurons. B3, Percentage of CB-positive neurons in the SNc, SNr, and VTA. $\mathrm{CB}$ was found preferentially in the VTA $(* * p<0.01)$.
mRNA expression of the two neurotransmitter synthesizing enzymes GAD and TH, two neuropeptides CCK and NT, three $\mathrm{Ca}^{2+}$-binding proteins $\mathrm{CB}, \mathrm{CR}$, and $\mathrm{PV}$, and nine $\mathrm{nAChR}$ subunits $\alpha 2-7$ and $\beta 2-4$ (Fig. 1). The aim was to determine whether a specific, potential nAChR-forming combination of subunits was associated with a particular molecular profile, a particular electrophysiological class or a particular anatomical location within the SN-VTA area. The cells included in the analysis expressed at least one of the neurotransmitter synthesizing enzymes mRNA, plus at least one of either the neuropeptides or the $\mathrm{Ca}^{2+}$-binding proteins mRNA, plus at least one nAChR subunit mRNA. Of the neurons characterized electrophysiologically, 70 of 79 fulfilled these criteria.

All but one electrophysiologically identified DA neuron expressed TH mRNA (49 of 50; the remaining neuron expressed only GAD). Gaba neurons expressed GAD (20 of 20); 19 of the 70 cells $(27 \%)$ coexpressed $\mathrm{TH}$ and GAD, as already reported under similar experimental conditions (Guyon et al., 1999). This molecular phenotype appeared independent of the electrophysiological class and location of the cell $(p=0.3$ and $p=0.9$, respectively) but age dependent (Fig. $2 A$ ). Coexpression of catecholaminergic and amino acidergic phenotypes appears to be a common phenomenon in the brain (Kosaka et al., 1987; Kaneko et al., 1990). In DA midbrain neurons, the DA-glutamate phenotype seems to predominante over the DA-GABA phenotype in adult animals (Kosaka et al., 1987; Campbell et al., 1991; Sulzer et al., 1998). However, the present data showing a peak of GAD/TH coexpression at postnatal day 16-17 suggests that the prevalence of the GABA phenotype is plastic and may be regulated developmentally.

Among the neuropeptides, CCK was distributed widely and NT was distributed very sparsely (Fig. 2B1); CCK mRNA was found more frequently in DA than in Gaba neurons $(p<0.01)$ (Fig. 2B2), whereas the sparse distribution of NT mRNA was not correlated with the occurrence of a particular Gaba subclass. Among the $\mathrm{Ca}^{2+}$-binding proteins, $\mathrm{CR}$ mRNA was detected in practically every neuron, whereas $\mathrm{PV}$ and $\mathrm{CB}$ mRNAs were more restricted in their distribution (Fig. 2B1). VTA neurons preferentially expressed CB mRNA $(p<0.01)$, regardless of neuron class (Fig. 2B3); PV mRNA was indicative of neither class nor location.

\section{nAChR subunit mRNAs in SN and VTA neurons}

Among the mRNAs of the nine nAChR subunits sampled, $\alpha 2$ mRNA was never detected, and $\alpha 4$ mRNA was found in practi- cally all neurons (69 of 70). The frequency distribution of the remaining $\mathrm{nAChR}$ subunit mRNAs is shown in Figure $3 A$; no single subunit was location specific; however, for some, the nAChR subunit mRNA distribution was strikingly class specific (Figs. $1,3 B$ ). $\alpha 5, \alpha 6$, and $\beta 3$ mRNA were almost exclusively ( $p<$ 0.001 ) encountered in DA neurons, and in a high proportion ( $>72 \%$ of DA neurons); $\alpha 3$ mRNA was also prevalent in DA neurons $(60 \%)$ but not significantly more $(p=0.06)$ than in Gaba neurons (35\%); $\beta 2$ mRNA provisionally appeared (see caveat in Materials and Methods) more frequently distributed in Gaba than in DA neurons; $\alpha 7$ mRNA was equally distributed (40\%) between classes, and $\beta 4$ mRNA was sparsely distributed but more frequently encountered in Gaba $(25 \%)$ than in DA $(12 \%)$ neurons. Hence, the vast majority of DA neurons expressed the $\alpha 4-\alpha 5-\alpha 6-\beta 3$ mRNAs, to which $\alpha 3$ mRNA could often be added, whereas the vast majority of Gaba neurons expressed the $\alpha 4-\beta 2$ pair occasionally associated with $\alpha 3$ mRNA.

DA neurons were remarkably similar in terms of the nAChR subunit mRNAs they expressed, regardless of anatomical location. In Gaba neurons, the available sample was too limited to allow meaningful comparisons; however, VTA Gaba neurons expressed exclusively the $\alpha 4-\beta 2-\alpha 3$ subunits, whereas SN Gaba neuron subunit expression was more diverse. The $\alpha 5, \alpha 6$, or $\beta 3$ mRNA, when expressed in Gaba neurons, was encountered exclusively in the Gaba-RS subclass of the $\mathrm{SNr}$ (three of three for $\alpha 5$, two of two for $\alpha 6$, four of four for $\beta 3$ ); in addition, four of five

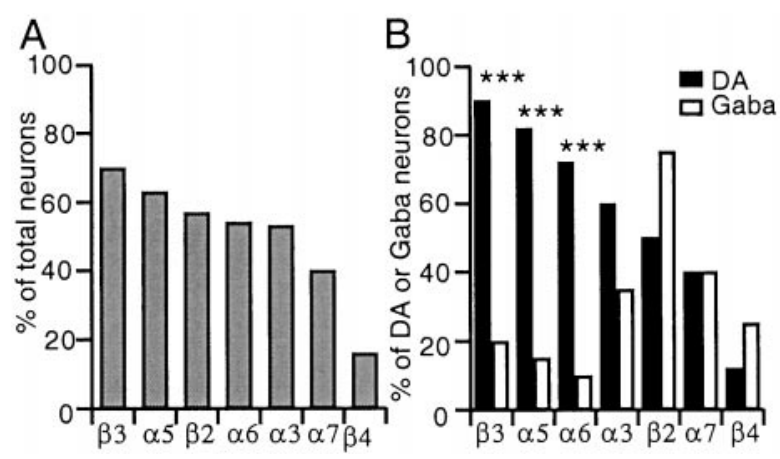

Figure 3. Frequency distribution of nicotinic subunit mRNAs in the SN and VTA. $A$, Nicotinic subunits are sorted by order of decreasing prevalence: subunit $\alpha 4$ was present in all neurons, and subunit $\alpha 2$ was present in none (data not shown). $B$, The same distribution segregated with respect to neuron class. $\beta 3, \alpha 5$, and $\alpha 6$ mRNAs are significantly more prevalent in DA than in Gaba neurons $(* * * p<0.001)$. 
Figure 4. Neurons containing subunit $\alpha 7$ mRNA exhibit fast currents gated by choline and ACh. Choline $(10 \mathrm{~mm} ; 30 \mathrm{msec})$ elicits identical current waveforms in DA and Gaba neurons (left panel). In the same neurons, ACh (1 mM; $30 \mathrm{msec})$ elicits different current waveforms (middle panel), in both of which a fast component can be recognized. In this and subsequent figures, currents were evoked from a holding potential of $-70 \mathrm{mV}$, and the width of the black box at the beginning of each trace indicates duration of pressure-pulse application. Agarose gels (right panel) corresponding to the DA and Gaba neuron show the presence of subunit $\alpha 7$ mRNA (gels truncated after the nAChR subunit wells).

of $\beta 4$ mRNA-containing Gaba neurons were in the SNr. Finally, $\alpha 7$ mRNA appeared with equal probability in VTA or SN neurons regardless of class $(p>0.99)$.

Expression of the less prevalent $\alpha 3, \alpha 7$, and $\beta 4$ mRNAs was evaluated for codistribution with the less prevalent molecular species $\mathrm{CB}, \mathrm{PV}$, and NT; the occurrence of $\alpha 3$ mRNA was thus found significantly correlated with that of the $\mathrm{Ca}^{2+}$-binding protein $\mathrm{CB}(p<0.05)$.

\section{Correlation of nAChR subunit mRNAs with nAChR currents}

In a subset $(n=37)$ of the 70 neurons on which single-cell RT-PCR was performed, the pharmacology of nicotinic agonistgated currents was assessed rapidly so as not to compromise the quality of the subsequent RT-PCR. By using a two-channel drug application pipette, two agonists could be tested on the somaproximal dendritic region of each neuron by fast, pressure-pulse applications of variable duration (see Materials and Methods). The drug combinations used were ACh (1 mm; $30 \mathrm{msec})$ with the putative $\alpha 7$-homomeric subtype-specific agonist choline (10 mM; $30 \mathrm{msec})$ in one set of neurons, and nicotine $(20 \mu \mathrm{M} ; 1 \mathrm{sec})$ with cytisine $(20 \mu \mathrm{m} ; 1 \mathrm{sec})$ in another set. Only 2 of the 37 neurons did not respond to any of the agonists applied, and both were Gaba VTA neurons.

The aim of the ACh/choline combination $(n=16)$ was combined with the single-cell RT-PCR results to validate the identification of an $\alpha 7$-homomeric type of current when gated by ACh under our experimental conditions. Choline elicited the characteristic $\alpha 7$-homomeric type of current waveform (Alkondon et al., 1997) in 7 of 16 neurons; $\alpha 7$ mRNA was detected in all choline-responsive neurons (Fig. 4) and absent in the cholineunresponsive neurons. ACh elicited multiphasic current waveforms; a component with fast activation kinetics was attributed to

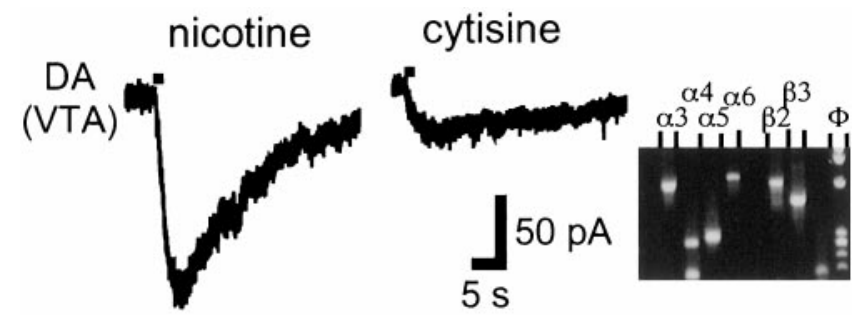

Figure 5. Nicotine elicits larger currents than cytisine in neurons lacking subunit $\beta 4$. Nicotine $(20 \mu \mathrm{M}$; left panel $)$ and cytisine $(20 \mu \mathrm{M}$; middle panel) were pressure-applied for $1 \mathrm{sec}$. Agarose gel (right panel; truncated after the nAChR subunit wells) shows the absence of subunit $\beta 4$.

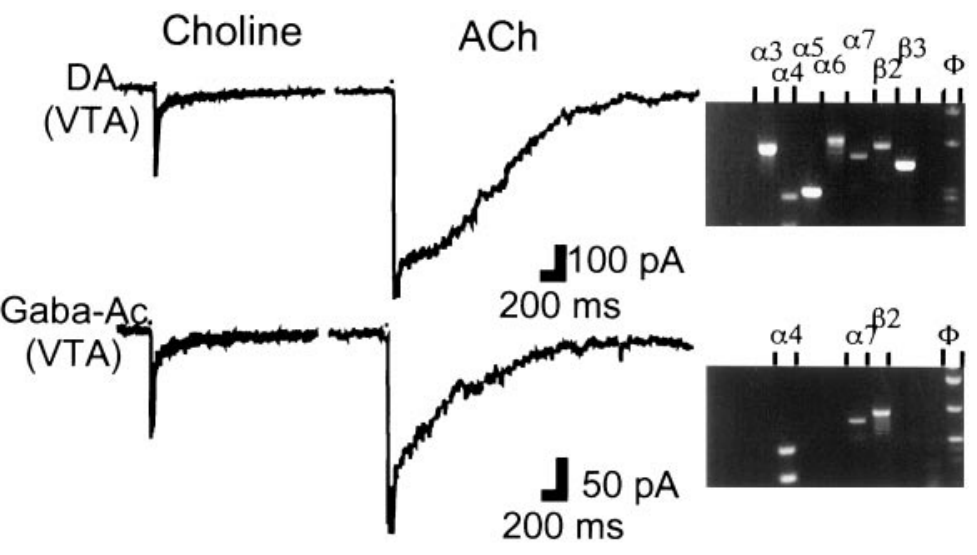

the $\alpha 7$-homomeric type of current and could be identified in five of seven of the choline-responsive and $\alpha 7$ mRNA-positive neurons (Fig. 4). Rise times of the fast current were similar in ACh $(22 \pm 4 \mathrm{msec})$ and choline-gated currents (13 $\pm 2 \mathrm{msec})$; current duration measured in choline $(86 \pm 11 \mathrm{msec})$ was therefore considered indicative of the time course of the ACh-gated $\alpha 7$ homomeric type of current. This current is essentially over in 100 msec and therefore cannot contribute to the ACh current waveform occurring later. Concerning these later ACh-elicited currents, the examples illustrated in Figure 4 show that, congruent with the single-cell RT-PCR results, ACh waveforms in DA neurons were clearly different from those in Gaba neurons. Later on, we present a detailed analysis of the ACh-gated currents on a larger sample of SN-VTA neurons.

Cytisine is considered a nicotinic agonist with higher affinity for $\beta 4$-containing $\mathrm{nAChRs,} \mathrm{in} \mathrm{both} \mathrm{reconstituted} \mathrm{(Luetje} \mathrm{and}$ Patrick, 1991) and native receptors (Zoli et al., 1998). Conflicting evidence for the role of cytisine and hence of $\beta 4$ subunit in DA release in the striatum has been presented (Grady et al., 1992; El-Bizri and Clarke, 1994). With the nicotine/cytisine combination $(n=21)$, cytisine elicited a larger current than nicotine in only one VTA Gaba neuron; otherwise, the cytisine response was between 0 and $44 \%$ of the corresponding nicotine response (Fig. $5)$. In none of those neurons was $\beta 4$ mRNA detected.

\section{Diversity of $\mathbf{n A C h R}$ currents in SN and VTA neurons}

An extensive biophysical and pharmacological investigation was performed on another set of SN-VTA neurons with electrophysiological properties identical to those described previously $(n=$ 73). First, we confirmed the postsynaptic location and nicotinic nature of the recorded currents. In a low $\mathrm{Ca}^{2+}(0.1 \mathrm{mM}) /$ high $\mathrm{Mg}^{2+}$ (10 mM) ACSF solution, which prevents sustained transmitter release, $\mathrm{ACh}$ and nicotine responses were identical in time course to those in regular $\operatorname{ACSF}(n=3)$; their amplitude, however, appeared slightly reduced, consistent with $\mathrm{Ca}^{2+}$ modulation of nAChR channels (Mulle et al., 1992; Liu and Berg, 1999) (data not shown). In another set of neurons, the nicotinic

Table 2. ACh-elicited current waveform parameters of slow nAChRmediated currents

\begin{tabular}{llll} 
& DA $(n=38)$ & Gaba-Ac $(n=8)$ & Gaba-RS $(n=7)$ \\
\hline Rise time & $251 \pm 22 \mathrm{msec}$ & $85 \pm 13 \mathrm{msec}^{* *}$ & $214 \pm 31 \mathrm{msec}$ \\
Amplitude & $249 \pm 25 \mathrm{pA}$ & $45 \pm 10 \mathrm{pA}^{*}$ & $194 \pm 57 \mathrm{pA}$
\end{tabular}

When an $\alpha$ 7-homomeric component was present, current parameters were measured at the break of its sharp exponential decay. ${ }^{*} p<0.05 ;{ }^{* *} p<0.01$. 

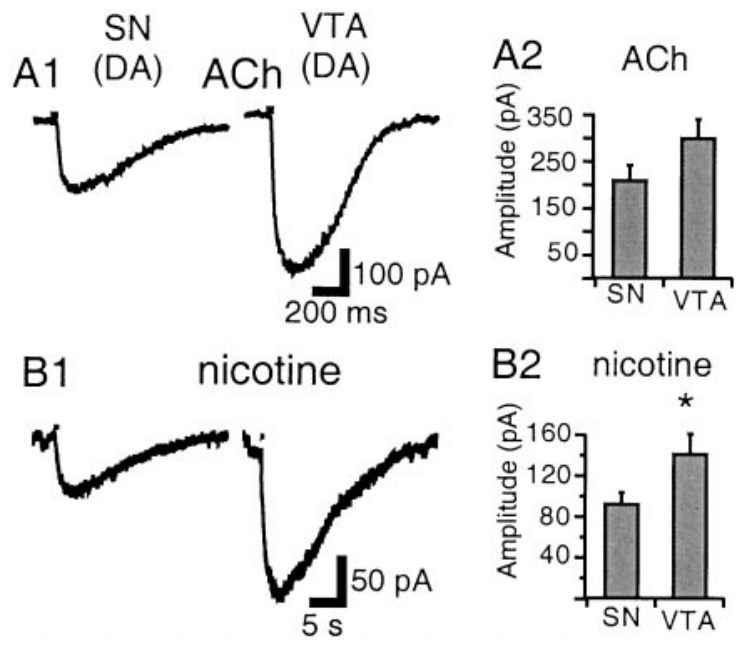

Figure 6. Nicotinic currents in DA neurons of the SN and VTA. A1, ACh (1 mM; $30 \mathrm{msec})$ elicits currents of similar waveform in the VTA and $\mathrm{SN}$, characterized by a round peak and sigmoid decay. B1, In the same neurons, nicotine (20 $\mu \mathrm{M} ; 300 \mathrm{msec})$ elicits much longer lasting currents. A2, Mean ACh-elicited current amplitude in the SN and VTA. B2, Mean nicotine-elicited current amplitude in the SN and VTA. Nicotine induces larger currents in the VTA than in the SN $(* p<0.05)$.

channel blocker mecamylamine $(10 \mu \mathrm{M})$ blocked all ACh/nicotine responses $(n=4)$ (data not shown).

ACh (1 mm; $30 \mathrm{msec}$ )-elicited and nicotine (20 $\mu \mathrm{M} ; 300 \mathrm{msec})-$ elicited currents were characterized in DA $(n=38)$ and Gaba $(n=20)$ neurons of the SN-VTA area. All neurons responded to $\mathrm{ACh}$, whereas nicotine responses were undetectable in three Gaba neurons. As noted previously, ACh current waveforms differed in shape and amplitude according to neuron class, whereas nicotine waveforms differed only in amplitude. In what follows, we will not mention the fast, putative $\alpha 7$-homomeric component when present in the ACh waveform; the later component, putatively mediated by heteromeric nAChRs, will be referred to as the slow component. Table 2 lists the ACh-elicited slow current parameters quantified in DA neurons and the two major Gaba subclasses of the SN-VTA (15 of 20 Gaba neurons).

ACh currents in DA neurons of the SNc, SNr, and VTA were similar in shape (Fig. 6A1). Peak current was reached slowly (114-543 msec), but current decay was relatively abrupt; the DA $\mathrm{ACh}$ waveform was thus characterized by a round peak and a sigmoid decay component (concave up). The nicotine current time course was $\sim 10 \times$ slower (rise time 1.6-4.9 sec) (Fig. 6B1), although response latency (see Materials and Methods) was equally short with $\mathrm{ACh}$ or nicotine. Both agonists elicited cur- rents of larger amplitude in the VTA $(n=16)$ than in the $\mathrm{SN}(n=$ $22)$; this difference was more pronounced with nicotine $(142 \pm 17$ vs $93 \pm 11 \mathrm{pA} ; p<0.05)$ (Fig. 6B2) than with ACh $(302 \pm 39$ vs $211 \pm 31 \mathrm{pA} ; p=0.07$ ) (Fig. 6A2).

ACh currents in the two major subclasses of Gaba neurons fell into two distinct categories with respect to activation kinetics and amplitude. In the Gaba-Ac neurons of the VTA and in a portion of the Gaba-RS neurons of the $\mathrm{SNr}$, peak current was reached relatively fast (50-150 msec) and decay was much slower (Fig. 7A1). This Gaba ACh waveform was thus characterized by a sharp peak and an exponential decay component (convex up); amplitudes were considerably and significantly smaller than in the other neuronal classes (Table 2). In the remaining Gaba-RS neurons of the $\mathrm{SNr}$, ACh waveforms resembled those of DA neurons; they exhibited a large amplitude and a slow rounded peak (89-328 msec), although the sigmoid decay component was not as pronounced (Fig. 7A2). By plotting current amplitude versus corresponding rise time of ACh currents, the two groups segregated, and it was apparent that many Gaba-RS neurons exhibited current rise times and amplitudes characteristic of DA neurons (Fig. 7B).

\section{Pharmacological properties of nAChRs in SN and VTA neurons}

MLA, a putative $\alpha 7$-specific nAChR antagonist, was tested for its ability to inhibit the fast currents elicited by ACh and choline. Choline pulses $(10 \mathrm{~mm} ; 30 \mathrm{msec}) 5 \mathrm{~min}$ apart did not cause any substantial nAChR desensitization (89-100\% of control responses; $n=4)$. MLA (1 nM), bath-perfused for $10 \mathrm{~min}$, antagonized the choline-elicited current $(91-100 \%$ block; $n=4)$. After a 15 min washout period, the current recovered to 23 and $29 \%$ of its control value $(n=2)$. These properties (Fig. $8 A 1)$ are typical of $\alpha 7$ homomeric nAChRs (Wonnacott et al., 1993; Palma et al., 1996). However, because ACh (1 mm; $30 \mathrm{msec})$ was applied to the same neurons after choline $(n=8)$, in addition to fast current antagonism (Fig. 8A2), it was noticed that MLA (1 nM) could antagonize the slow peak of the ACh waveform (Fig. 8B2), a component that, as already shown, is independent of the presence of the $\alpha 7$ mRNA.

This MLA sensitivity of slow nAChR-mediated currents was further investigated with ACh (1 mm; $30 \mathrm{msec})$ and nicotine (20 $\mu \mathrm{M} ; 300 \mathrm{msec})$ coapplications. MLA (1-10 nM) differentially antagonized ACh-elicited responses (Table 3). Responses in 8 of 30 neurons tested were unaffected by MLA ( $<11 \%$ inhibition), in 4 of 30 were highly MLA sensitive ( $>85 \%$ inhibition), and in the rest were partially sensitive (inhibition between 34 and 61\%; mean $=46 \pm 2 \% ; n=18)$. MLA antagonism was already maximal at a concentration of $1 \mathrm{~nm}$ because switching from $1 \mathrm{nM}$

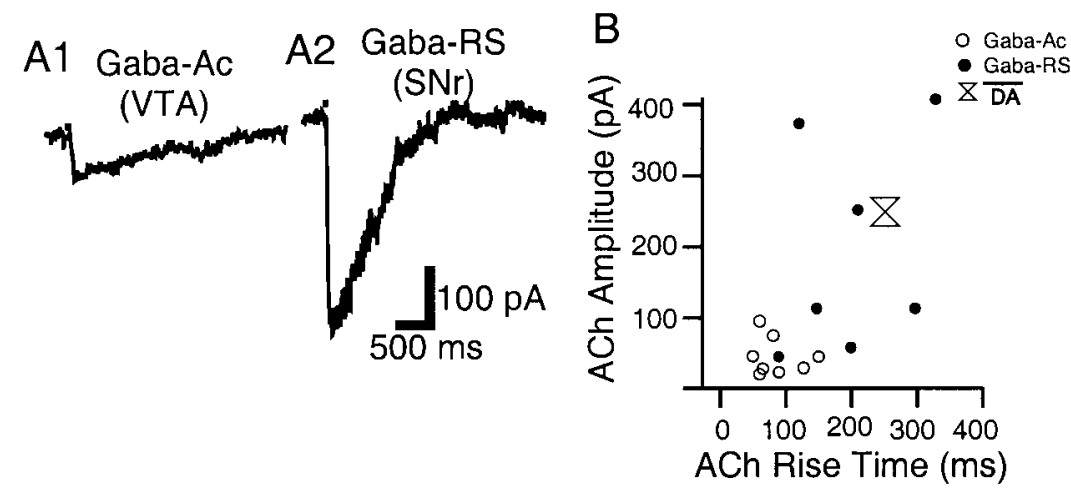

Figure 7. ACh-elicited currents in Gaba neurons of the SN and VTA. A1, In the Gaba-Ac subclass of the VTA, ACh elicits current waveforms characterized by a sharp peak, exponential decay, and small amplitude. $A 2$, In the Gaba-RS subclass of the $\mathrm{SNr}$, the ACh current waveform is often slower and of larger amplitude. B, ACh elicited current amplitude plotted versus corresponding rise time in Gaba-Ac (O) and Gaba-RS neurons (๑); mean ACh-elicited current amplitude versus mean rise time in DA neurons was also reported (double triangle). 

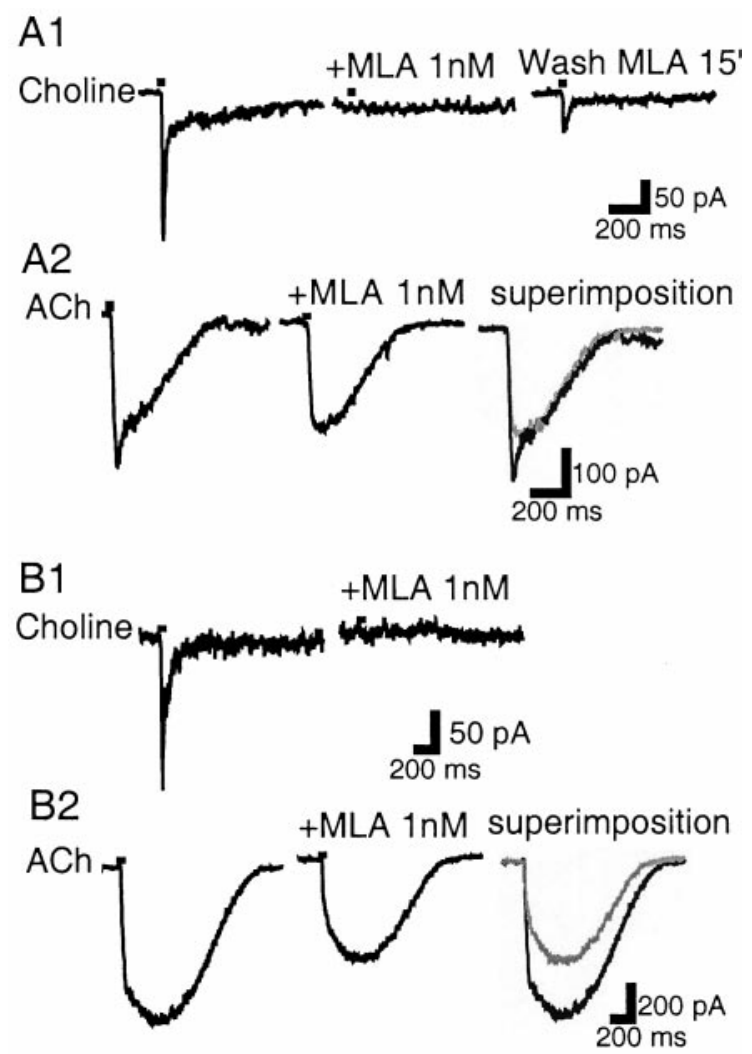

Figure 8. MLA affects two different types of currents. A1, In a VTA DA neuron, MLA (1 nM) blocks the choline-gated current, which partially recovers after a $15 \mathrm{~min}$ wash period. $A 2$, In the same neuron, MLA blocks the fast component of the ACh-gated current without affecting the slower component. B1, In another VTA DA neuron, MLA (1 nM) blocks the choline-gated current. B2, In the same neuron, the ACh-gated current does not show a clear fast component; however, MLA inhibits the slow peak current occurring later. In the superimposition panels, MLA trace is in gray.

to $10 \mathrm{~nm}$ MLA did not cause a greater inhibition (responses in 10 nM MLA were $105-116 \%$ of those in $1 \mathrm{~nm}$ MLA; $n=3$ ). In addition, MLA (1 nM) was not measurably reversed after a $15 \mathrm{~min}$ wash period $(n=15)$.

Nicotine-elicited responses exhibited the same MLA sensitivity profile (after verification that a $10 \mathrm{~min}$ period between nicotine pulses was sufficient to recover from nAChR desensitization; $n=$ 4 ); however, MLA inhibition was only $24 \pm 3 \%$, significantly smaller than that of ACh-elicited responses $(p<0.001 ; n=12)$.

Thus, to sum up, in SN-VTA neurons, ACh and nicotine can elicit slow nAChR-mediated currents that are as sensitive to MLA as the fast type. These two MLA-sensitive current types can be distinguished by their kinetics and their differential recovery from MLA blockade.

Table 3. Distribution of MLA-probed neurons in terms of subclass and MLA (1-10 nM) sensitivity

\begin{tabular}{llll} 
& $\begin{array}{l}\text { Not } \\
(\mathrm{I}<11 \%)\end{array}$ & $\begin{array}{l}\text { Partially } \\
(34<\mathrm{I}<61 \%)\end{array}$ & $\begin{array}{l}\text { Highly } \\
(\mathrm{I}>85 \%)\end{array}$ \\
\hline DA $(n=25)$ & 6 & 18 & 1 \\
Gaba-Ac $(n=2)$ & 2 & 0 & 0 \\
Gaba-RS $(n=3)$ & 0 & 0 & 3
\end{tabular}

Neurons were assigned to a not, partially, or highly MLA-sensitive group based on percentage inhibition (I) of control ACh-elicited current.
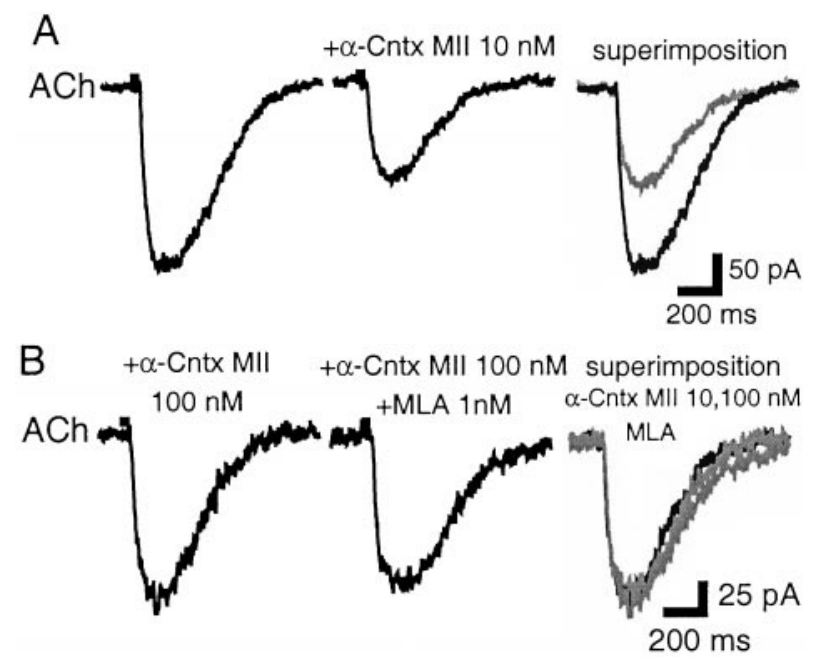

Figure 9. $\alpha$-conotoxin MII inhibits the MLA-sensitive component of ACh-gated currents. $A$, In an SNc DA neuron, $\alpha$-conotoxin MII (10 nM) inhibits the ACh-gated current. In the panel labeled superimposition, the MLA trace is in gray. $B$, In the same neuron, increased concentration of $\alpha$-conotoxin MII (100 nM) does not result in greater inhibition (note change in scale); addition of MLA ( $1 \mathrm{nM})$ to the $\alpha$-conotoxin MII (100 $\mathrm{nM})$ also has no effect (middle). In the superimposition panel, the $\alpha$-conotoxin MII (100 nM) and MLA traces are in gray. $\alpha$-Cntx MII, $\alpha$-Conotoxin MII.

Table 3 categorizes all MLA-probed neurons (ACh as agonist) in terms of neuron class and MLA sensitivity. A minority of DA neurons $(24 \%)$ are not MLA sensitive; most are only partially MLA sensitive. However, DA neurons with nAChR-mediated currents totally blocked by MLA (1/25) do occur; these are referred to as highly MLA sensitive in Table 3 . The available sample of Gaba neurons was small; however, it appears that VTA Gaba-Ac neurons are not MLA sensitive. Concerning the $\mathrm{SNr}$ Gaba-RS neurons, it should be noted that these exhibited the ACh-elicited current waveform characteristic of DA neurons and were highly MLA sensitive.

We interpret partial inhibition of the nAChR-mediated currents by MLA, which could not be overcome by greater antagonist concentrations, as being caused by the presence of two nAChR subtypes: one is maximally blocked by $1 \mathrm{nM}$ MLA and the other is not affected. Most DA neurons possess both subtypes, and their agonist-induced responses are therefore partially inhibited by MLA. However, it appears that the biophysical properties of the two subtypes do not differ greatly. The current waveform in the presence of MLA also exhibited the characteristic rounded peak and sigmoid decay (Fig. 8B2); thus, rise time of AChelicited current was slightly but not significantly increased in the presence of MLA $(295 \pm 31 \mathrm{msec}$ vs $271 \pm 31 \mathrm{msec} ; p=0.08 ; n=$ 19 DA neurons).

We further investigated the pharmacological properties of these nAChR subtypes with the antagonist $\alpha$-conotoxin MII, at concentrations inhibiting striatal DA release (Kulak et al., 1997; Kaiser et al., 1998) and reported to be specific for $\alpha 3 \beta 2 *$-nAChRs (10-100 nM). ACh-elicited currents were not affected by $\alpha$-conotoxin MII (10 nM) in two of eight DA neurons; in the remaining six neurons, $\alpha$-conotoxin MII (10 nM) inhibited ACh currents by $40 \pm 4 \%(20-48 \%)$ without an observable effect on activation kinetics (not quantified) (Fig. 9A). This block was maximal because switching from a 10 to a $100 \mathrm{~nm}$ solution did not increase the degree of $\alpha$-conotoxin MII antagonism $(n=3)$ (Fig. $9 B$ ). There was an occlusion between $\alpha$-conotoxin MII and MLA 


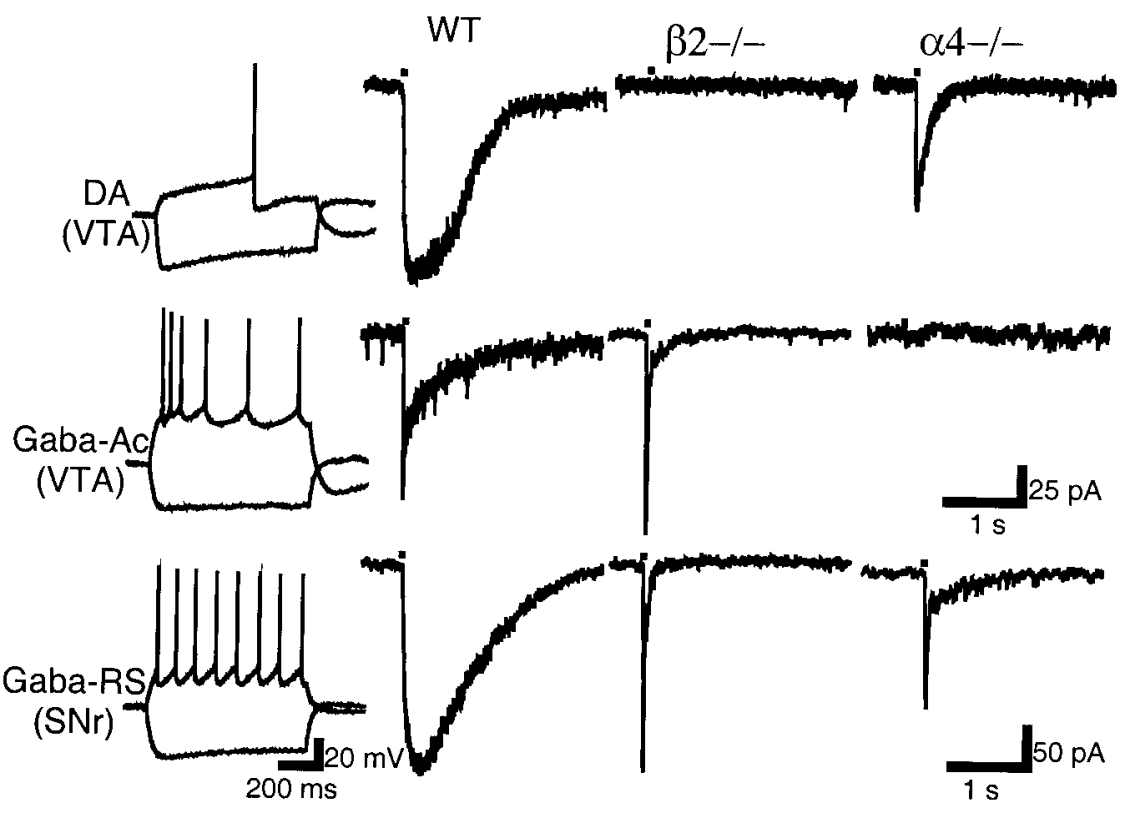

Figure 10. Neuron classes and their ACh-elicited currents in the SN and VTA of WT and nAChR subunit null mutant mice. Electrophysiological classes (left panel) and ACh-elicited current waveforms in WT (second panel from left) were similar to those described in rat. In $\beta 2-/-$ mice, only a fast, $\alpha 7$ homomeric type of ACh-gated current could be recorded in the illustrated neuronal subclasses (third panel). In $\alpha 4-/-$ mice, a slow current could be elicited only in DA neurons (right panel). Calibration in second row applies also to top row. antagonism because addition of MLA ( $1 \mathrm{nM})$ to the toxin solution did not increase the degree of antagonism (MLA + toxin responses were $91-108 \%$ of those of toxin alone; $n=3$ including a toxin-insensitive neuron) (Fig. $9 B$ ). These results therefore indicate that the MLA-sensitive nAChR subtype is also $\alpha$-conotoxin MII sensitive, because both antagonists induced a comparable degree of inhibition in the same proportion of neurons, and their effects were occlusive.

The antagonist $\mathrm{DH} \beta \mathrm{E}$ at a concentration of $2 \mu \mathrm{M}$ discriminates, in functional assays, between two different $\beta 2 *$-nAChR subtypes (Marks et al., 1999). Ach- and nicotine-elicited currents in DA and Gaba neurons were blocked by DH $\beta E(2 \mu \mathrm{M})(83-$ $100 \%$ inhibition; $n=7$ including two neurons that were partially inhibited by $\alpha$-conotoxin MII). These results therefore indicate that both the MLA/ $\alpha$-conotoxin MII-sensitive and -insensitive $\mathrm{nAChR}$ subtypes on SN-VTA neurons are $\mathrm{DH} \beta \mathrm{E}$ sensitive (data not shown).

\section{nAChR currents in nAChR subunit null mutant mice}

Further refinement in the identification of the subunit composition of nAChRs present in the SN and VTA was attempted by examining nAChR-mediated currents in $\beta 2$ (Picciotto et al., 1995), $\alpha 4$ (Marubio et al., 1999), and $\alpha 7$ (Orr-Urtreger et al., 1997) null mutant mice. First, it was ascertained that neuronal classes and their ACh-elicited currents were similar in rat and mouse; in WT mice $(n=15)$, identical ACh-elicited current waveforms were segregated to the same neuronal classes as in rat (Fig. 10, first and second panels from left). In $\beta 2$ null mutant mice $(n=19)$, the only ACh-gated current that could be elicited in

Table 4. ACh-elicited current waveform parameters in DA neurons of WT and $\alpha 4-/-$ mice

\begin{tabular}{llc} 
& WT $(n=8)$ & $\alpha 4-/-(n=15)$ \\
\hline Amplitude & $132 \pm 26 \mathrm{pA}$ & $72 \pm 7 \mathrm{pA}^{* *}$ \\
Rise time & $242 \pm 38 \mathrm{msec}$ & $96 \pm 17 \mathrm{msec}^{* *}$ \\
Decay $T_{1 / 2}$ & $562 \pm 66 \mathrm{msec}$ & $316 \pm 47 \mathrm{msec}^{* *}$
\end{tabular}

Decay $T_{1 / 2}$ was the time measured between peak and half maximal amplitude. ${ }^{* *} p<$ 0.01 .
DA, Gaba-Ac, and Gaba-RS neurons was the fast, putative $\alpha 7$ homomeric type of current (Fig. 10, right panel). However, in the $\mathrm{SNr}$, in addition to this fast current, a slow current was still evoked in a subclass of Gaba neurons characterized by burst firing (the minority type in rat); further investigation of this $\beta 2$ independent current was not undertaken. In $\alpha 4$ null mutants $(n=$ 23), slow currents were evoked in most DA neurons (15 of 18); however, ACh current amplitude, rise time, and decay time were all significantly smaller than in WT mice $(p<0.01)$ (Table 4; Fig. 10 , right panel). No slow currents could be elicited in the Gaba-Ac or Gaba-RS neuron subclasses (Fig. 10, right panel). In $\alpha 7$ null mutants, the only noted difference with WT mice was the absence of the fast, putative $\alpha 7$-homomeric type component from the ACh waveform (data not shown).

MLA sensitivity was also investigated. Similarly to rat, in WT mice ACh-elicited currents in DA neurons were partially inhibited (45 $\pm 12 \% ; n=4)$, and their rise time was increased slightly but significantly (from $195 \pm 53 \mathrm{msec}$ to $246 \pm 78 \mathrm{msec} ; n=4$; $p<0.01$ ) by MLA (1 nM) (Fig. 11, left). MLA sensitivity was totally abolished in DA neurons of $\alpha 4-/-$ mice $(112 \pm 6 \%$ of control currents; $n=5$ ) (Fig. 11, middle) but remained intact in DA neurons of $\alpha 7-/-$ mice (43 and 55\% inhibition; $n=2$ ) (Fig. 11, right). As in rat, the ACh-elicited current in SNr Gaba-RS neurons of WT mice was highly MLA sensitive (79 and 82\% inhibition; $n=2$ ) (data not shown); as already mentioned, this current was abolished in $\alpha 4$ null mutants.

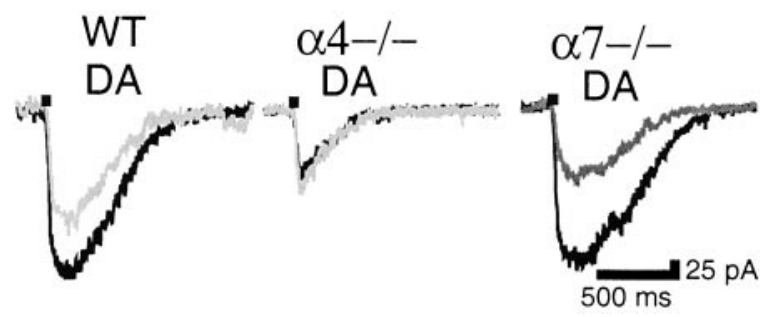

Figure 11. MLA-sensitive currents in WT and $\mathrm{nAChR}$ subunit null mutant mice. Left, DA neurons in WT mice are partially inhibited by MLA (1 nM); middle, MLA sensitivity is abolished in $\alpha 4-/-$ mice; right, MLA sensitivity is not affected in $\alpha 7-/-$ mice. MLA traces are in gray. 
Results obtained in null mutant mice thus confirm the previous identification of MLA-sensitive and MLA-insensitive nAChR subtypes. One important question is whether the MLAinsensitive nAChR subtype in WT mice is identical to the MLAinsensitive $\mathrm{nAChR}$ species present in $\alpha 4-/-$ mice. A kinetic analysis suggests a negative answer: in WT mice, MLA blockade uncovered an nAChR-mediated current with slow activation kinetics (rise time $\sim 250 \mathrm{msec}$ ) and sigmoid decay, whereas the nAChR-mediated current in $\alpha 4$ null mutants had fast activation kinetics (rise time $\sim 100 \mathrm{msec}$ ) and exponential decay (Table 4; Fig. 11). The residual nAChR-mediated current in $\alpha 4-/-$ mice is currently being investigated in our laboratory.

\section{DISCUSSION}

The present work shows that somatodendritic nAChRs on DA and Gaba projection neurons of the SN and VTA fall into four different subtypes, each possessing a particular complement of nAChR subunits and exhibiting different ACh-gated current waveforms and pharmacological properties. One subtype present on neurons that lack the $\alpha 7$ gene or mRNA exhibits nanomolar sensitivity to MLA.

\section{Methodological considerations}

An objective of the present study was to relate electrophysiological recordings and molecular detection of nAChR mRNAs at the single-cell level. Yet, some caution is required when interpreting single-cell PCR studies. In general, the distribution of nAChR subunit mRNAs in the SN-VTA revealed by single-cell RT-PCR tallies well with in situ hybridization results (Le Novère et al., 1996), which showed moderate to high levels of $\alpha 4-6$ and $\beta 2-3$ mRNA. The case of $\alpha 3, \alpha 7, \beta 2$, and $\beta 4$ mRNA requires a more specific comment. $\alpha 3$ mRNA was detected in $\sim 60 \%$ of DA neurons with single-cell PCR, but its signal was very low in in situ hybridization experiments. This suggests that $\alpha 3$ mRNA is expressed in a relatively large proportion of DA neurons but at low level. With regard to $\alpha 7$ mRNA, single-cell PCR shows its presence in $40 \%$ of DA neurons, whereas the $\alpha 7$ mRNA signal in in situ hybridization experiments, as well as $\alpha$-bungarotoxin binding in autoradiography experiments, is very low (Zoli et al., 1998). The tight correspondence between detection of $\alpha 7$ mRNA and electrophysiological response to choline is strong proof for the existence of functional $\alpha 7$-containing nAChRs in some SN-VTA neurons. As described in Materials and Methods, the set of oligomers for $\beta 2$ used in the single-cell PCR experiments was likely to detect a large number of false negative cells. The use of another set of oligomers in a restricted sample showed that $\beta 2$ mRNA was present in all DA neurons analyzed. This latter evidence together with previous in situ hybridization (Le Novère et al., 1996) and immunocytochemistry (Hill et al., 1993) findings strongly suggests that $\beta 2 \mathrm{mRNA}$ and protein are present in all neurons. This notion is also supported by the evidence that slow nAChR-mediated currents disappear from all DA neurons in $\beta 2$ null mice (Picciotto et al., 1998; and present results). $\beta 4$ mRNA was detected in $\sim 10 \%$ of DA neurons and $25 \%$ of Gaba neurons. $\beta 4$ mRNA was not detected previously in DA neurons by using PCR technique on SNc homogenates (Elliott et al., 1998) or in situ hybridization experiments (Le Novère et al., 1996). Overall, these techniques converge on the concept that $\beta 4$ is rarely expressed in DA or Gaba neurons of the SN-VTA. Its expression and participation in functional nAChRs, however, is indirectly suggested by the finding that some Gaba neurons in the $\mathrm{SNr}$ still show slow nAChR currents in $\beta 2$ null mice.

\section{nAChR subtypes as signatures of neuron class diversity}

In the present study, in addition to nAChR subunit mRNA distribution, we investigated that of various molecular markers to disclose any potential association between them. The only significant correlation was that of the $\mathrm{Ca}^{2+}$-binding protein $\mathrm{CB}$ with $\alpha 3$ mRNA, and hence presumably with $\alpha 3 *$-nAChRs. In contrast, neuron class was highly correlated with a specific distribution pattern of nAChR subunit mRNA and nAChR-mediated current waveform. Thus, nAChR subunit expression and nicotinic agonist-gated currents were remarkably similar in DA neurons of the SNc, SNr, and VTA and different from those of Gaba neurons in the same area; moreover, Gaba neurons exhibited diverse electrophysiological properties warranting their classification into subclasses as elsewhere in the CNS (Cauli et al., 1997; Parra et al., 1998), and nAChRs, in general, followed this diversity. In this regard, because it was not investigated further, we mention again here the occurrence, in $\beta 2-/-$ mice, of a non- $\beta 2 *$-nAChR slow current restricted to a particular Gaba neuron subclass in the SNr.

\section{nAChR subtypes in SN and VTA neurons}

To uncover the various nAChR functional subtypes, we used kinetic and pharmacological analysis in the same neuronal populations in which single-cell RT-PCR was performed. These revealed the presence of four different nAChR subtypes on the somatodendritic region of SN-VTA neurons (discussed below). Similar studies in null mutant mice confirmed the identification of these four subtypes and added some useful constraints on their subunit composition. In the following, we evaluate the data presented in this work, as well as previous relevant findings, to propose a hypothesis about the molecular composition of the different $\mathrm{nAChR}$ subtypes. We follow the rules currently accepted for assembly of functional nAChR oligomers (for review, see Corringer et al., 2000) and the recommended nomenclature (Lukas et al., 1999).

\section{The $\alpha 7$-homomeric subtype}

$\alpha 7$ mRNA was detected in less than half of neurons in the SN-VTA. In all $\alpha 7$-expressing neurons, a choline, and in most cases an ACh-elicited current with fast kinetics, was observed that was blocked by MLA (1 nM) and measurably recovered within 15 min of drug removal. These properties are typical of the $\alpha 7$ homomeric subtype identified in other anatomical locations and experimental systems (Wonnacott et al., 1993; Alkondon et al., 1997; Papke et al., 2000). Characterization of $\alpha 7$ null mutant mice (Orr-Urtreger et al., 1997) confirms that with deletion of the $\alpha 7$ subunit, the identified $\alpha 7$-homomeric component disappears, whereas ACh-gated waveforms beyond $100 \mathrm{msec}$ are not affected. Therefore, present and previous evidence converges to the identification of choline and ACh-gated fast currents with an $(\alpha 7)_{5^{-}}$ nAChR oligomer. On the basis of mRNA expression of the $\alpha 7$ subunit, this subtype is encountered with equal probability in the SN or VTA and in DA as well as Gaba neurons.

\section{The GABA-Ac subtype}

The ACh-elicited current waveform of this nAChR subtype is identical to that of Type IB [when the $(\alpha 7)_{5}$-nAChR is also present] and Type II nAChRs, suggested to comprise $\alpha 4$ and $\beta 2$ subunits (Alkondon and Albuquerque, 1993). The present work supports this contention because Gaba-Ac neurons express almost exclusively mRNA for $\alpha 4$ and $\beta 2$, and no current could be evoked in $\beta 2$ (Picciotto et al., 1995) or $\alpha 4$ (Marubio et al., 1999) 
null mutant mice. The only other subunit detected in Gaba-Ac neurons was $\alpha 3$, which could be transported to nerve terminals or form somatodendritic nAChRs together with $\alpha 4$ and $\beta 2$. If the latter case is true, kinetic or pharmacological analyses could not resolve any difference between a putative $(\alpha 4)_{2}(\beta 2)_{3}$ (the most prevalent) and an $\alpha 3 \alpha 4(\beta 2)_{3}$-nAChR oligomer. On the basis of nAChR subunit mRNA distribution and kinetic analysis, this subtype appears present on some Gaba-RS neurons of the $\mathrm{SNr}$ in addition to the Gaba-Ac neurons of the VTA.

\section{The DA subtypes}

In addition to the putative $(\alpha 7)_{5}$-nAChR oligomer, two nAChR subtypes were uncovered on DA neurons. Their ACh-elicited waveforms have the same kinetic properties characterized by a round peak and a sigmoid decay. Their pharmacological properties, however, differed because only one was inhibited by MLA (1 $\mathrm{nM})$ or $\alpha$-conotoxin MII (10 nM), whereas both subtypes were blocked by $\mathrm{DH} \beta \mathrm{E}(2 \mu \mathrm{M})$. Most DA neurons (72\%) possess both subtypes, a significant minority (24\%) possess only the MLA/ $\alpha$ conotoxin MII-insensitive subtype, and a very small proportion possess only the MLA/ $\alpha$-conotoxin MII-sensitive subtype. Again, based on comparison of ACh-elicited waveforms, our data further imply that none of these subtypes is identical to the putative $(\alpha 4)_{2}(\beta 2)_{3}$-nAChR oligomer of Gaba-Ac neurons characterized by a sharp peak and exponential decay.

Results from nAChR subunit mRNA expression and agonistelicited currents in $\mathrm{nAChR}$ subunit null mutant mice add some constraints on the subunit composition of the two subtypes. All DA neurons express $\alpha 4$ and $\beta 2$, whereas $\beta 3, \alpha 5, \alpha 6, \alpha 3$, and $\alpha 7$ are expressed by $\sim 90,80,70,60$, and $40 \%$ of neurons, respectively. Results from null mutant mice demonstrate that both subtypes contain $\beta 2$ and $\alpha 4$ subunits, but $\beta 2$ is necessary for assembly of functional receptors, whereas residual subunits in $\alpha 4-/-$ mice still assemble to form a functional oligomer(s) with biophysical properties different from WT nAChR subtypes. In addition, our data demonstrate that the $\alpha 7$ subunit is present in neither subtype because the residual slow current waveforms in $\alpha 7-/-$ mice were identical to the WT counterparts. The subunit composition of the functional oligomer(s) in $\alpha 4-/-$ mice is an important question that is not addressed in the present work but is currently investigated in our laboratory.

Previous evidence suggested that an $\alpha 3 \beta 2$ interface confers $\alpha$-conotoxin MII sensitivity (Cartier et al., 1996). An $\alpha 6 \beta 2$ interface is also plausible in view of the high percentage of sequence identity between $\alpha 3$ and $\alpha 6$, notably in the ligand binding site (Le Novère and Changeux, 1995). We thus propose that it is the $\alpha 6$ subunit that confers the observed MLA $/ \alpha$-conotoxin MII sensitivity to most DA and part of Gaba-RS neurons. In the same expression system, the $\alpha 6 \beta 4$ combination was twice as sensitive to MLA as the $\alpha 3 \beta 4$ one (Fucile et al., 1998). Moreover, in immunoprecipitation experiments, $\alpha 6$-containing receptors exhibited a high affinity for $\alpha$-conotoxin MII and MLA (Vailati et al., 2000). Finally, in DA neurons, $\alpha 6$ mRNA levels are $\sim 20$ times higher than those of $\alpha 3$ (Le Novère et al., 1996), and the high proportion of MLA-sensitive DA neurons (76\%) agrees more closely with the frequency distribution in DA neurons of subunit $\alpha 6(72 \%)$ than with that of $\alpha 3(60 \%)$.

AChR-elicited slow current waveforms on DA neurons exhibited a particular signature. We propose that this reflects the presence of the $\alpha 5$ subunit in both subtypes. In expression systems, $\alpha 5^{*}$-nAChRs exhibited biophysical properties (RamirezLatorre et al., 1996; Wang et al., 1996; Gerzanich et al., 1998;
Nelson and Lindstrom, 1999) that could account for the large amplitude, rounded peak, and sigmoid decay observed in both subtypes. Indeed, it is noteworthy that hippocampal interneurons containing the association of $\alpha 4-\alpha 5-\beta 2$ subunits showed an AChgated current waveform similar to the one we portray here (Porter et al., 1999, their Fig. 3). The $\beta 3$ subunit has high sequence identity with $\alpha 5$ (Le Novère and Changeux, 1995), but the biophysical properties it confers when incorporated in nAChRs are not significant (Groot-Kormelink et al., 1998).

We propose that, unlike $\alpha 5, \beta 3$ does not enter into the composition of DA somatodendritic nAChR subtypes but is targeted to their terminals. This hypothesis is supported by immunocytochemical studies showing that the $\beta 3$ subunit product is transported to the projection areas of the catecholaminergic nuclei that express it, in both mesostriatal (Forsayeth and Kobrin, 1997; Arroyo-Jiménez, 2000) and coeruleus-hippocampal systems (Léna et al., 1999). We thus propose that the MLA/ $\alpha$-conotoxin MII nAChR subtype has an $\alpha 4 \alpha 6 \alpha 5(\beta 2)_{2}$ composition with a possible minor contribution of $\alpha 3 \alpha 4 \alpha 5(\beta 2)_{2}$ composition. This oligomer is present on DA neurons and on some Gaba-RS neurons of the $\mathrm{SNr}$. On the other hand, the MLA/ $\alpha$-conotoxin MII-insensitive subtype would tentatively possess the $(\alpha 4)_{2} \alpha 5(\beta 2)_{2}$ composition.

\section{Physiological implications of nAChR diversity}

The nicotinic modulation of DA release from striatal preparations has been exploited as a model system pertinent to tobacco abuse. Yet, in vivo investigations demonstrate that $\mathrm{nAChRs}$ in the somatodendritic region of the VTA are of greater importance than those located in the accumbal terminal region in mediating sustained DA release (Nisell et al., 1994) and nicotine selfadministration (Corrigall et al., 1994). Here, we show that nicotine-elicited currents in DA neurons were of significantly larger $(53 \%)$ amplitude in the VTA than in the SN, despite a remarkably similar nAChR subunit distribution in the two areas. This implies a higher density of functional receptors on the somatodendritic region of VTA neurons that would greatly impact on nicotine-elicited impulse flow, ultimately leading to DA release in striatal terminal areas.

Sensitivity to estimated low nanomolar MLA concentrations of various aspects of nicotine addiction has been used to implicate $\alpha 7$-homomeric nAChRs in these behaviors (Schilstrom et al., 1998; Nomikos et al., 1999). The present work clearly establishes that nanomolar MLA sensitivity is present in the absence of $\alpha 7$ subunit gene or mRNA, which implies that it can no longer be invoked to signify exclusive involvement of $\alpha 7$-homomeric or putative $\alpha 7^{*}$ heteromeric nAChRs (Yu and Role, 1998; Cuevas et al., 2000).

Nicotine self-administration is mostly investigated in the DA projection from the VTA to the ventral striatum. However, addiction is increasingly viewed as involving all large scale neural circuits encompassing the basal ganglia, cerebral cortex, and thalamus that are modulated by the VTA, SNc, and SNr (Berke and Hyman, 2000). In this context, the contribution of GABAergic inhibitory projection neurons with diverse nicotinic response properties should not be underestimated. The diversity and distribution pattern of the $\mathrm{nAChR}$ subtypes that we illustrate here suggest that nicotinic modulation of the midbrain system regulating reinforcement and motor behavior might be more elaborate than previously thought. 


\section{REFERENCES}

Alkondon M, Albuquerque EX (1993) Diversity of nicotinic acetylcholine receptors in rat hippocampal neurons. I. Pharmacological and functional evidence for distinct structural subtypes. J Pharmacol Exp Ther 265:1455-1473.

Alkondon M, Pereira EF, Cortes WS, Maelicke A, Albuquerque EX (1997) Choline is a selective agonist of $\alpha 7$ nicotinic acetylcholine receptors in the rat brain neurons. Eur J Neurosci 9:2734-2742.

Arroyo-Jiménez MM (2000) Localization of the $\alpha 4$ and $\beta 3$ subunits of the neuronal nicotinic acetylcholine receptor in the rodent central nervous system. PhD thesis, Universidad Miguel Hernández, Albacete, Spain.

Baron JA (1986) Cigarette smoking and Parkinson's disease. Neurology 36:1490-1496.

Berke JD, Hyman SE (2000) Addiction, dopamine, and the molecular mechanisms of memory. Neuron 25:515-532.

Campbell KJ, Takada M, Hattori T (1991) Co-localization of tyrosine hydroxylase and glutamate decarboxylase in a subpopulation of single nigrotectal projection neurons. Brain Res 558:239-244.

Cartier GE, Yoshikami D, Gray WR, Luo S, Olivera BM, McIntosh JM (1996) A new $\alpha$-conotoxin which targets a3b2 nicotinic acetylcholine receptors. J Biol Chem 271:7522-7528.

Cauli B, Audinat E, Lambolez B, Angulo MC, Ropert N, Tsuzuki K, Hestrin S, Rossier J (1997) Molecular and physiological diversity of cortical nonpyramidal cells. J Neurosci 17:3894-3906.

Clarke PB, Pert A (1985) Autoradiographic evidence for nicotine receptors on nigrostriatal and mesolimbic dopaminergic neurons. Brain Res 348:355-358.

Corrigall WA, Coen KM, Adamson KL (1994) Self-administered nicotine activates the mesolimbic dopamine system through the ventral tegmental area. Brain Res 653:278-284.

Corringer PJ, Le Novère N, Changeux JP (2000) Nicotinic receptors at the amino acid level. Annu Rev Pharmacol Toxicol 40:431-458.

Cuevas J, Roth AL, Berg DK (2000) Two distinct classes of functional $\alpha 7$-containing nicotinic receptor on rat superior cervical ganglion neurons. J Physiol (Lond) 525:735-746.

El-Bizri H, Clarke PB (1994) Blockade of nicotinic receptor-mediated release of dopamine from striatal synaptosomes by chlorisondamine and other nicotinic antagonists administered in vitro. Br J Pharmacol 111:406-413.

Elliott KJ, Jones JM, Sacaan AI, Lloyd GK, Corey-Naeve J (1998) 6-hydroxydopamine lesion of rat nigrostriatal dopaminergic neurons differentially affects nicotinic acetylcholine receptor subunit mRNA expression. J Mol Neurosci 10:251-260.

Fallon JH, Loughlin SE (1995) Substantia nigra. In: The rat nervous system (Paxinos G, ed) pp 215-237. San Diego: Academic.

Forsayeth JR, Kobrin E (1997) Formation of oligomers containing the $\beta 3$ and $\beta 4$ subunits of the rat nicotinic receptor. J Neurosci 17:1531-1538.

Fucile S, Matter JM, Erkman L, Ragozzino D, Barabino B, Grassi F, Alemà $\mathrm{S}$, Ballivet $\mathrm{M}$, Eusebi $\mathrm{F}$ (1998) The neuronal $\alpha 6$ subunit forms functional heteromeric acetylcholine receptors in human transfected cells. Eur J Neurosci 10:172-178.

Fuxe K, Janson AM, Jansson A, Andersson K, Eneroth P, Agnati LF (1990) Chronic nicotine treatment increases dopamine levels and reduces dopamine utilization in substantia nigra and in surviving forebrain dopamine nerve terminal systems after a partial di-mesencephalic hemitransection. Naunyn Schmiedebergs Arch Pharmacol 341:171-181.

Gerzanich V, Wang F, Kuryatov A, Lindstrom J (1998) $\alpha 5$ Subunit alters desensitization, pharmacology, $\mathrm{Ca}^{++}$permeability and $\mathrm{Ca}^{++}$modulation of human neuronal $\alpha 3$ nicotinic receptors. J Pharmacol Exp Ther 286:311-320.

Grace AA, Onn SP (1989) Morphology and electrophysiological properties of immunocytochemically identified rat dopamine neurons recorded in vitro. J Neurosci 9:3463-3481.

Grady S, Marks MJ, Wonnacott S, Collins AC (1992) Characterization of nicotinic receptor-mediated $\left[{ }^{3} \mathrm{H}\right]$ dopamine release from synaptosomes prepared from mouse striatum. J Neurochem 59:848-856.

Groot-Kormelink PJ, Luyten WH, Colquhoun D, Sivilotti LG (1998) A reporter mutation approach shows incorporation of the "orphan" subunit $\beta 3$ into a functional nicotinic receptor. J Biol Chem 273:15317-15320.

Guyon A, Laurent S, Paupardin-Tritsch D, Rossier J, Eugène D (1999) Incremental conductance levels of $\mathrm{GABA}_{\mathrm{A}}$ receptors in dopaminergic neurones of the rat substantia nigra pars compacta. J Physiol (Lond) 516:719-737.

Hill Jr JA, Zoli M, Bourgeois JP, Changeux JP (1993) Immunocytochemical localization of a neuronal nicotinic receptor: the $\beta 2$-subunit. J Neurosci 13:1551-1568.

Kaiser SA, Soliakov L, Harvey SC, Luetje CW, Wonnacott S (1998) Differential inhibition by $\alpha$-conotoxin-M II of the nicotinic stimulation of $\left[{ }^{3} \mathrm{H}\right]$ dopamine release from rat striatal synaptosomes and slices. J Neurochem 70:1069-1076.

Kaneko T, Akiyama H, Nagatsu-I, Mizuno N (1990) Immunohistochem- ical demonstration of glutaminase in catecholaminergic and serotoninergic neurons of rat brain. Brain Res 507:151-154.

Kosaka T, Kosaka K, Hataguchi Y, Nagatsu I, Wu JY, Ottersen OP, Storm-Mathisen J, Hama K (1987) Catecholaminergic neurons containing GABA-like and/or glutamic acid decarboxylase-like immunoreactivities in various brain regions of the rat. Exp Brain Res 66:191-210.

Kulak JM, Nguyen TA, Olivera BM, McIntosh J (1997) $\alpha$-Conotoxin MII blocks nicotine-stimulated dopamine release in rat striatal synaptosomes. J Neurosci 17:5263-5270.

Lambolez B, Audinat E, Bochet P, Crepel F, Rossier J (1992) AMPA receptor subunits expressed by single Purkinje cells. Neuron 9:247-258.

Le Novère N, Changeux JP (1995) Molecular evolution of the nicotinic acetylcholine receptor: an example of multigene family in excitable cells. J Mol Evol 40:155-172.

Le Novère N, Zoli M, Changeux JP (1996) Neuronal nicotinic receptor $\alpha 6$ subunit mRNA is selectively concentrated in catecholaminergic nuclei of the rat brain. Eur J Neurosci 8:2428-2439.

Léna C, de Kerchove d'Exaerde A, Cordero-Erausquin M, Le Novère N, Arroyo-Jimenez MM, Changeux JP (1999) Diversity and distribution of nicotinic acetylcholine receptors in the locus coeruleus neurons. Proc Natl Acad Sci USA 96:12126-12131.

Liu QS, Berg DK (1999) Extracellular calcium regulates responses of both alpha 3 -and alpha 7-containing nicotinic receptors on chick ciliary ganglion neurons. J Neurophysiol 82:1124-1132.

Luetje CW, Patrick J (1991) Both $\alpha$ - and $\beta$-subunits contribute to the agonist sensitivity of neuronal nicotinic acetylcholine receptors. J Neurosci 11:837-845.

Lukas RJ, Changeux JP, Le Novère N, Albuquerque EX, Balfour DJ, Berg DK, Bertrand D, Chiappinelli VA, Clarke PB, Collins AC, Dani JA, Grady SR, Kellar KJ, Lindstrom JM, Marks MJ, Quik M, Taylor PW, Wonnacott S (1999) International Union of Pharmacology. XX. Current status of the nomenclature for nicotinic acetylcholine receptors and their subunits. Pharmacol Rev 51:397-401.

Marks MJ, Whiteaker P, Calcaterra J, Stitzel JA, Bullock AE, Grady SR, Picciotto MR, Changeux JP, Collins AC (1999) Two pharmacologically distinct components of nicotinic receptor-mediated rubidium efflux in mouse brain require the $\beta 2$ subunit. J Pharmacol Exp Ther 289:1090-1103.

Marubio LM, Arroyo-Jimenez MM, Cordero-Erausquin M, Léna C, Le Novère N, de Kerchove d'Exaerde A, Huchet M, Damaj MI, Changeux JP (1999) Reduced antinociception in mice lacking neuronal nicotinic receptor subunits. Nature 398:805-810.

Mulle C, Léna C, Changeux JP (1992) Potentiation of nicotinic receptor response by external calcium in rat central neurons. Neuron 8:937-945.

Nelson ME, Lindstrom J (1999) Single channel properties of human $\alpha 3$ AChRs: impact of $\beta 2, \beta 4$ and $\alpha 5$ subunits. J Physiol (Lond) 516:657-678.

Nisell M, Nomikos GG, Svensson TH (1994) Infusion of nicotine in the ventral tegmental area or the nucleus accumbens of the rat differentially affects accumbal dopamine release. Pharmacol Toxicol 75:348-352.

Nomikos GG, Hildebrand BE, Panagis G, Svensson TH (1999) Nicotine withdrawal in the rat: role of $\alpha 7$ nicotinic receptors in the ventral tegmental area. NeuroReport 10:697-702.

O'Brien CP, McLellan AT (1996) Myths about the treatment of addiction. Lancet 347:237-240.

Orr-Urtreger A, Goldner FM, Saeki M, Lorenzo I, Goldberg L, De Biasi M, Dani JA, Patrick JW, Beaudet AL (1997) Mice deficient in the $\alpha 7$ neuronal nicotinic acetylcholine receptor lack $\alpha$-bungarotoxin binding sites and hippocampal fast nicotinic currents. J Neurosci 17:9165-9171.

Palma E, Bertrand S, Binzoni T, Bertrand D (1996) Neuronal nicotinic $\alpha 7$ receptor expressed in Xenopus oocytes presents five putative binding sites for methyllycaconitine. J Physiol (Lond) 491:151-161.

Papke RL, Meyer E, Nutter T, Uteshev VV (2000) $\alpha 7$ Receptorselective agonists and modes of $\alpha 7$ receptor activation. Eur J Pharmacol 393:179-195.

Parra P, Gulyas AI, Miles R (1998) How many subtypes of inhibitory cells in the hippocampus? Neuron 20:983-993.

Paxinos G, Watson C (1986) The rat brain in stereotaxic coordinates, Ed 2. San Diego: Academic.

Picciotto MR, Zoli M, Léna C, Bessis A, Lallemand Y, Le Novère N, Vincent P, Pich EM, Brulet P, Changeux JP (1995) Abnormal avoidance learning in mice lacking functional high-affinity nicotine receptor in the brain. Nature 374:65-67.

Picciotto MR, Zoli M, Rimondini R, Léna C, Marubio LM, Pich EM, Fuxe K, Changeux JP (1998) Acetylcholine receptors containing the $\beta 2$ subunit are involved in the reinforcing properties of nicotine. Nature 391:173-177.

Pidoplichko VI, DeBiasi M, Williams JT, Dani JA (1997) Nicotine activates and desensitizes midbrain dopamine neurons. Nature 390:401-404

Porter JT, Cauli B, Tsuzuki K, Lambolez B, Rossier J, Audinat E (1999) Selective excitation of subtypes of neocortical interneurons by nicotinic receptors. J Neurosci 19:5228-5235.

Poth K, Nutter TJ, Cuevas J, Parker MJ, Adams DJ, Luetje CW (1997) 
Heterogeneity of nicotinic receptor class and subunit mRNA expression among individual parasympathetic neurons from rat intracardiac ganglia. J Neurosci 17:586-596.

Ramirez-Latorre J, Yu CR, Qu X, Perin F, Karlin A, Role L (1996) Functional contributions of $\alpha 5$ subunit to neuronal acetylcholine receptor channels. Nature 380:347-351.

Schilstrom B, Svensson HM, Svensson TH, Nomikos GG (1998) Nicotine and food induced dopamine release in the nucleus accumbens of the rat: putative role of $\alpha 7$ nicotinic receptors in the ventral tegmental area. Neuroscience 85:1005-1009.

Sharples CGV, Kaiser S, Soliakov L, Marks MJ, Collins AC, Washburn M, Wright E, Spencer JA, Gallagher T, Whiteaker P, Wonnacott S (2000) UB-165: a novel nicotinic agonist with subtype selectivity implicates the $\alpha 4 \beta 2 *$ subtype in the modulation of dopamine release from rat striatal synaptosomes. J Neurosci 20:2783-2791.

Sulzer D, Joyce MP, Lin L, Geldwert D, Haber SN, Hattori T, Rayport $\mathrm{S}$ (1998) Dopamine neurons make glutamatergic synapses in vitro. J Neurosci 18:4588-602.
Vailati S, Moretti M, Balestra B, McIntosh M, Clementi F, Gotti C (2000) $\beta 3$ subunit is present in different nicotinic receptor subtypes in chick retina. Eur J Pharmacol 393:23-30.

Wang F, Gerzanich V, Wells GB, Anand R, Peng X, Keyser K, Lindstrom J (1996) Assembly of human neuronal nicotinic receptor $\alpha 5$ subunits with $\alpha 3, \beta 2$, and $\beta 4$ subunits. J Biol Chem 271:17656-17665.

Wonnacott S, Albuquerque EX, Bertrand D (1993) Methyllycaconitine: a new probe that discriminates between nicotinic acetylcholine receptor subclasses. Methods Neurosci 12:263-275.

Yu CR, Role LW (1998) Functional contribution of the $\alpha 5$ subunit to neuronal nicotinic channels expressed by chick sympathetic ganglion neurones. J Physiol (Lond) 509:667-681.

Yung WH, Häusser MA, Jack JJ (1991) Electrophysiology of dopaminergic and non-dopaminergic neurones of the guinea-pig substantia nigra pars compacta in vitro. J Physiol (Lond) 436:643-667.

Zoli M, Léna C, Picciotto MR, Changeux JP (1998) Identification of four classes of brain nicotinic receptors using $\beta 2$ mutant mice. J Neurosci 18:4461-4472. 